\title{
The Activities of Adl Wal Ihsane in the Neighbourhoods. How to Build a 'Non-Legal' Consensus from a 'Tolerated' Conflict
}

\author{
Merieme Yafout
}

\begin{abstract}
Based on observation of the activities of the female members of the Moroccan Islamist movement Justice and Spirituality (Al Adl Wal Ihsane, AWI) at neighbourhood level, this chapter analyses the conception of development fostered by this movement and tries to answer the following questions: how do conflicting visions of development (those of AWI, the authorities and other associations) live together in the same neighbourhood, and what do the interactions between these different active participants tell us about modes of government on the local scale? If we view Islamists as agents of human development, and religious education and spirituality as important elements in this development, we see how complex the social and political relations are that the Islamist movement has with power and with society as a whole. The interactions of Islamist movements with various local players highlight a dialectic between conflict and consensus based on a 'Western' hegemonic model of development. This dialectic allows other strategies to find expression — strategies that flourish in daily activities - and other conceptions of what is seen as a 'good' way of conducting one's life. Intentional or not, strategies of discharge, differentiation, discretion, competition or compliance, and the alternative modes of governance and conduct of life that this article highlights, show that the relationships between different players cannot be reduced just to conflict or consensus, and that their behaviour cannot be explained solely as a form of rejection or acceptance. The neo-liberal paradigm of development can comprise both a common ground and a place of conflict between quite different models of society.
\end{abstract}

Assoc $^{1}$ is a women's association founded in 2006 that works in a poor neighbourhood of Casablanca. The association operates an economic micro-project

1 This is one of the women's associations that I observed during field research I conducted as part of my doctoral thesis on the status of women in Islamist movements in Morocco (Yafout,

(C) MERIEME YAFOUT, 2017 | DOI 10.1163/9789004349551_006

This is an open access chapter distributed under the terms of the prevailing CC-BY-NC license at the time of publication. 
for local women who also benefit from literacy courses, awareness campaigns, and workshops that provide training in manual work. In addition to these activities, Assoc provides extra classes for students of different ages and conducts other long-term activities such as health campaigns, legal awareness classes and lectures on women's issues. According to one official from Assoc, all of these activities are meant to help women evolve from their status as mere consumers and gain financial independence and participate fully in development. Through these activities, we motivate women to emerge from their cocoons and attend various training courses that educate them to adopt a spirit of production and productivity and, above all, a critical mind, which will prevent them from falling into the trap of Wahhabism.'2

In principle, these activities are no different from those of the majority of active women's groups in poor neighbourhoods and rural areas. Literacy programmes, awareness campaigns, workshops giving training in manual work, and cooperatives are all part of the current hegemonic model of development consisting in particular of assistance to micro-projects, micro-credit, incomegenerating activities, literacy, etc. Similarly, the vocabulary and lexicon used by Assoc are those of the dominant dogma with its references to economic efficiency, participation and individual responsibility. However, these activities can be seen in a quite different light if we take into account the fact that Assoc is forced to deploy an arsenal of precautions simply in order to exist, and in particular to conduct its activities in such a way that they are not prohibited. Indeed, two members of its governing bodies belong to the Islamist movement Justice and Spirituality (Al Adl Wal Ihsane, AWI); ${ }^{3}$ a movement considered as

2012). The research was conducted between 2008 and 2012. The data analysed in this chapter are mainly the result of participant observation of the activities of the women studied and of semi-structured interviews I conducted with them. To ensure the anonymity of the association, neither its name nor the name of the neighbourhood will be cited. [The author's pseudonymous name for this association is 'Ass', which I have replaced, passim, by the less equivocal name 'Assoc' - translator's note.].

2 Interview with one of Assoc's officials; Casablanca, 23 January 2009.

3 The history of this movement is linked to that of its founder, Abdessalam Yassine, who in 1974 sent a letter of advice to King Hassan II. Following this act, he suffered a series of acts of repression. In 1982 he created the Islamic charitable association that in 1987 adopted the slogan Al Adl Wal Ihsane (Justice and Spirituality), and, until his death in 2012, led radical opposition to the Moroccan political regime. The position taken by this movement led to the imprisonment and repression of its leaders and many of its members. During the 1990s, the movement expanded dramatically in universities and then became the largest Moroccan Islamist movement. Until now, AWI has refused to engage itself in institutional political life 
'not legal but tolerated'4 This proximity shifts the focus of the analysis from 'development' to 'development conflicts', highlighting the competition, differences and alternative modes of government at the local level.

The history of the AWI movement has been marked by its conflict with the monarchy. Indeed, since its birth in 1974 it has opposed the very bases of the latter: its hereditary character and its religious legitimacy. ${ }^{5}$ This is what explains its ambiguous status, reflected in the journalistic description of the movement as 'semi-tolerated'. Having failed to establish a change from above by persuading the head of the regime to reform the country, ${ }^{6}$ this movement is in favour of a change of society from the bottom up and places the concept of tarbiya (education) at the centre of its programmes. In AwI's theory, this concept derives its meaning from emphasising the importance of the human being and his or her happiness in earthly life and in the hereafter, thus establishing the link between a spiritual dimension that aims to change individuals from within and the values of social justice and dignity. The primary purpose of education, it claims, is to help make the human being 'free and independent', living 'with dignity' - and this objective can be achieved only if human beings suffer neither poverty nor injustice (Yassine, 1998). It is on the basis of this logic that the movement campaigns for social justice and is critical of the neo-liberal policies adopted by the state, which in its view ignore the facts and are ineffective, alienating, elitist, and produce injustice. AWI criticises the fact that the state accepts the 'ready-made recipes' imposed by hegemonic forces that consider the human being as a resource, as a 'consumer' and as a 'market' (Yassine, 1994, 189). However, this does not prevent the movement

but advocates non-violence and gradual change through education. It was one of the key players of the 20 February movement, which was initiated in 2011 as part of the 'Arab Spring'.

4 This expression is frequently used by the media to describe the legal status of AWI. See, for example, the article in TelQuel (2015).

5 The monarchy in Morocco bases its religious legitimacy on the principle of the 'Commander of the Faithful' — a traditional title reinvented during the reign of Hassan I granting the King a double 'mission': the safeguarding of religion and the management of public affairs. See Tozy (1999).

6 Abdessalam Yassine, at the time a senior figure in education and training, a former follower of the Boutchichiya zawiya (a Sufi brotherhood), sent a letter to King Hassan II requesting that he seeks redemption (attawba) and calling on him to 'take the initiative in the authentic rebirth of Islam'. The King's reaction was to intern Yassine in a hospital wing for tuberculosis patients, and then in a mental asylum for a total of three and a half years. Yassine is considered to have been one of the leading ideologues of Islamism (Tozy, 2009, 72) from 1973 to his death in December 2012; he wrote dozens of books setting out his project and his vision of Muslim history, of modern society and the state. 
from using the data produced by this dominant dogma. So it draws on international statistics and reports, including those that rank countries according to human development indices, to show the negative impact of these policies on the daily lives of Moroccans. The sectors of education and health, it claims, have been continually at risk since the adoption of structural adjustment programmes. Through the privatisation of several sectors, the opening up of the economy to international markets, internal economic liberalisation, and the increasing financial dependency of Morocco on investors and foreign lenders, these policies have, it is claimed, caused widening inequalities.

These critiques bring out the very different conception of development promoted by AWI: it views the state as a central agent of development and therefore establishes an ideal-typical construction of the role of a 'good government' whose priority is to deconstruct dependency on the West and to adopt a strategy that takes into account local contexts, with their own norms, values and structures. As Abdessalam Yassine noted, a 'good government' should adopt an education policy that 'frees us from alienation' (Yassine, 1994, 120), producing, in different areas including industry, skills that are essential for liberating Muslims from their status as 'consumers, importers and debtors' (Yassine, 1994, 182). So it is a reading of development focused simultaneously on Third World and nationalist values that emerges from these criticisms; a relatively interventionist conception of the state, different from the one developed by liberal Islamists of the Justice and Development Party (Parti de la justice et du développement, PJD). ${ }^{7}$ Thus, to a concept of development considered as superficial and alienating, the AWI movement prefers a concept of education that puts human beings at the centre of all 'real' development by focusing on their spiritual, social and economic fulfilment.

However, the critical vision of state development policies adopted by the AWI movement contradicts its earlier assessment of the Assoc association, even though Assoc is close to AWI. Assoc pursues activities that are 'mundane' and 'ordinary' compared to what other associations do, and undoubtedly fits into the development policies and liberalisation reforms introduced by the

7 The PJD is an Islamist party and has been in government since 2011, following the early elections held as part of the 'Arab Spring. It was created in 1996 following the integration of a group of members of the Islamist Movement of Unification and Reform (Mouvement de l'unification et de la réforme: MUR) into the party of the Constitutional Democratic Popular Movement (Mouvement populaire démocratique constitutionnel: MPDC) created in 1967 by Abdelkrim Al Khatib. Under the colours of this party, members of the MUR participated in elections for the first time in 1997, before the party changed its name, in 1998, to the Justice and Development Party (Parti de la justice et du développement: PJD) and continued to prepare for its gradual entry into institutional politics. 
government at the local level. This assessment lies at the origin of this chapter. Based on observation of the activities of the women members of AWI at neighbourhood level, this chapter tries to show how the different view of development fostered by AWI is realised, how conflicting visions of development (those of AWI, the authorities and other associations) live together in the same neighbourhood, and what the interactions between these different active participants tell us about modes of government on the local scale. The neighbourhood will thus be considered as a place where the conceptions, activities, convergences, divergences and strategies of different active participants all fit together.

Thanks to its existence as 'tolerated' despite being 'non-legal', the AwI movement has, since the late 1990s, proceeded to create neighbourhood associations. These provide it with a legal framework in which residents can approach it without fear. However, the creation of an association by AwI members must be achieved without the knowledge of the authorities and, for the association to exist and carry out its activities, a number of precautions and adaptations are necessary, as explained below. It is also important to note that community action is only complementary to other AWI activities in the neighbourhood. Despite its status, the presence of AWI in the neighbourhood is still based on the educational activities it carries out as an Islamist movement that sees itself as legal. ${ }^{8}$ Thus, the women members of AWI studied in this paper act in the neighbourhood primarily as a branch of the national women's section that conducts spiritual education work and 'consciousness raising. Then, depending on how closely they are controlled by the authorities, they act through one or more associations that provide development activities like all the other associations'.

While observing the various actions performed by women members of AWI in the neighbourhood under consideration, I paid particular attention to the Assoc women's association for social development. Of the seven members who form its executive office, two are members of AwI while the five others are sympathisers. Aged between 25 and 35, they are conducting an economic micro-project that benefits almost forty residents in the neighbourhood. Early in the morning, certain women come into the association's premises to bake

8 AWI members state that several verdicts pronounced by Moroccan law courts confirm that the movement is indeed legal. 
their own bread, while others prefer to do so at home and bring it to the association. At 11:30 a.m., they begin to sell these products in a small shop belonging to the local association. 'All the women who live in the surrounding streets buy our products; they know that it's clean and it's properly made', says a young woman responsible for sales in the shop. ${ }^{9}$ Afternoons are devoted to the different workshops open to women of the neighbourhood. Thus, one of the four little rooms on the premises is used by women of various ages taking literacy classes provided by two young women, each of them supervising one group. Thirty-eight women benefit from these courses and, as only one room is available for education, the supervisors are forced to divide them into two groups: the first group is taught between 2 p.m. and 4 p.m.; the second from 4 p.m. to 6 p.m. Soumaya, one of the supervisors, tells us that the number of women who want to get involved in reading and writing keeps increasing but, unfortunately, we have only one room. To solve this problem, the board members have managed to establish a partnership with a nearby school that opens its rooms from 6 p.m. onwards so as to cater for other women.' 10

The second room on the premises is reserved for learning crafts. Three workshops are held jointly: a sewing workshop set up in a corner equipped with sewing machines; a glass painting workshop in another corner; and a ceramic workshop in a third corner. The third room, meanwhile, opening onto the kitchen and equipped with a large oven, is intended for learning the culinary arts: women come here to swap and prepare different recipes, and their products are also sold in the aforementioned shop: Moroccan-style pancakes (msemen, baghrir), rolls, cakes, etc. At night, from 7 p.m. onwards, extra lessons for children and teenagers are provided. Direct support from AWI members is more important here: "The teaching "sisters" or "brothers"11 of the youth section have access to the free extra lessons, while the parents of recipients pay a nominal fee to the association', says the association's president. ${ }^{12}$

In addition to these daily activities, the board of the association organises weekly or monthly activities: health campaigns, legal awareness classes, lectures on women's issues, etc. Moreover, the treasurer of Assoc says that the association supports several women economically: in addition to the aforementioned forty women, there are also those who, thanks to various workshops, have set up small-scale sewing projects or bake cakes to order, for

9 Interview; 23 January 2009.

$10 \quad$ Interview with an Assoc literacy teacher; Casablanca, 23 January 2013.

11 The terms 'sister' and 'brother' are part of the lexicon usually employed by the militants of the Islamist movement to refer to one another.

Interview with the president of Assoc; Casablanca, 23 January 2009. 
example. With the exception of the secretary, who is paid a small sum, the work of the board members and workshop supervisors is voluntary. Thus, the treasurer of the association explains that the association earns ten santimat for each product sold in the store. This provides us with just enough to pay the rent for the premises and the local store and the various expenses: water, electricity [...] As for equipment, such as ovens, tables, sewing machines, kitchen utensils and so on, they are usually donations. ${ }^{13}$ In addition to the activities held within the association, others are organised from time to time in penitentiaries or orphanages, and the board of the association partners with colleges and high schools to sensitise teenagers to the dangers of drugs and alcohol and prevent all forms of juvenile delinquency.

Volunteers are motivated by a wide range of 'moral sentiments': commitment, altruism, self-sacrifice. But not these alone. Some are also driven by a love of community work or by the desire to occupy their free time, to communicate with others, to find work opportunities, and to feel useful. The association represents a friendly and feminine space where everyone knows everyone else, including the beneficiaries. In addition, mothers like it there because the activities they carry out in this space do not conflict with their roles as mothers. On the contrary, their maternal role is facilitated. In addition, various financial resources ensure the survival of the association: the income from the sale of products covers the major expenses (rent, water, electricity) while donations from benefactors and partnerships provide free premises for literacy classes.

To complement these resources, the association's board has prepared an application for financial aid from USAID ${ }^{14}$ and other international organisations, as well as from the National Initiative for Human Development (Initiative nationale du développement humain, INDH). The latter is part of a social and solidarity policy that Morocco adopted in the late 1990s and is one of those projects that are given priority treatment and media coverage as they are associated with the King (Bono, 2009; Catusse, 2011). Launched in 2005, this initiative funds local development micro-projects in order to fight against poverty by providing the poor with the means of breaking out of poverty by themselves (Bono, 2010 and 2013). It likewise encourages charitable activity. If the activities carried out by Assoc are no different from those performed by other neighbourhood associations, applying for funding from the INDH and international

\footnotetext{
13 Interview with the treasurer of Assoc; Casablanca, 23 January 2009.

14 The us Agency for International Development (USAID) says it supports projects in Morocco in the fields of economy and employment, for participation in governance, education and social reforms as well as for gender equality. See https://www.usaid.gov/ morocco (accessed on 1 June 2016).
} 
agencies constitutes a tactic for obtaining additional resources and a legitimation that does not necessarily amount to an endorsement of reigning dogmas. The fact remains that this strategy, which validates the compliance of Assoc's activities with the hegemonic model so heavily criticised elsewhere by AWI, constitutes an active participation in this model and, more generally, is a way of spreading this dominant paradigm. ${ }^{15}$

3

\section{Strategies of Differentiation, Compliance and Restriction in the Community Field}

While these programmes seem to converge with those of other associations active in the same neighbourhood, and with development policies more generally undertaken by public authorities and international organisations, interviewees try to assign to them a different meaning, which in fact confirms the ideological link between members of the executive office of Assoc and the AWI movement. Take literacy, for example; for these people, it assumes the following meaning: 'For us, literacy is not limited to learning how to read and write. Indeed, through this operation, we transmit a body of knowledge whose primary aim is to know God [...] This is for us a community framework that combines traditional programmes with an awakening of consciences and a spiritual education. ${ }^{16}$

Literacy, then, becomes a means of inculcating a system of values in its beneficiaries. One interviewee reveals that, at first, some women resort to the association 'out of curiosity' but that subsequently they may break off their activity with it because of family commitments or a certain fatigue, or simply due to a lack of motivation. To avoid this type of failure, the leaders of Assoc motivate participants by highlighting the Islamic model: 'We motivate women to play a positive role in their circle by drawing on the historical models of the female companions of the Prophet, the Hadith [the words and deeds of the Prophet], and koranic verses: this makes them more easily convinced of the virtues of community action.'17

15 This constrained participation, which stems from opportunism, a tactic of recognition, or a strategy aiming at efficiency and a very specific goal, was already highlighted by Weber (2006) and is very common in the world of development, given its bureaucratisation (Hibou, 2012; Kemp and Berkovitch, 2013).

16 Interview with an Assoc literacy teacher; Casablanca, 23 January 2013.

17 Interview with an Assoc official; Casablanca, 23 January 2009. 
The awakening of consciences and the spiritual education mentioned by the interviewees recall the educational project sponsored by AWI since the 1980 . According to this project, the individual must change from within to realise his or her spiritual journey to God. But change from within can only be achieved if the individual has not suffered from injustice. Thus, education is presented as a multidimensional process of change that acts first on the individual, presented as the main agent in the change, then spreads throughout society and reduces injustice. One of the basic mechanisms is coaching people with the aim of 'awakening their consciences.' This education 'from below' requires an AWI member to 'be ubiquitous among the people, in addition to being really close to all the social, economic and political difficulties the people are forced to suffer', ${ }^{18}$ and 'the awakening of consciences' is achieved by coaching, spreading the ideas of the movement, and acting as a role model. It is in this context that we must understand the community action and all the activities carried out by AWI members in the neighbourhood, as well as the implications of their 'coaching' the people.

For AWI members, this difference in the meaning attributed to community activities marks a move away from the hegemonic meaning imposed by Western players, which in their view is 'superficial. ${ }^{19}$ In the case of literacy, for example, while the hegemonic sense is limited to learning how to read and write, the implementation of a 'broader' meaning - insofar as it includes the behavioural and spiritual dimensions attributed to it by AWI - sets it apart from other players in this sector. AWI is, however, not the only body that works towards the education of women. In highly concrete terms, the movement faces two types of competition that help to distinguish it. First, the state has taken a firm grip on this activity following the reform of its religious policy based on a bureaucratisation of the religious bodies managing mosques: ${ }^{20}$ in 2005, the Ministry of Habous and Islamic Affairs began the feminisation of the religious bodies in charge of managing mosques. It proceeded to train Murshidat (female preachers $)^{21}$ and female trainers who provide literacy classes for women in mosques. These trainers have the status of civil servants. Literacy classes

18 These are the words of an interviewee; I spoke to her, together with a female AWI member, in Casablanca on 28 May 2009 for my doctoral research.

19 In the words of the previous interviewee.

20 Tozy notes that this religious policy, based-inter alia —on the management and supervision of the use of mosques and the training of the technicians of worship, dates from the early 1980 s (Tozy, 2009, 66), but that it has gained momentum since the terrorist attacks of 16 May 2003 in Casablanca (Tozy, 2013). 
and sermons result in the creation of paid jobs. While these public policies undoubtedly increase the provision of literacy and thereby form part of a practice of development, they take on a particular meaning in the Moroccan political context: they express a desire to compete with Islamist movements, starting with AWI, on their own ground; a strategy designed to restrict the audience for these movements by limiting the scope of their actions in this area.

At the same time, the community field is also a field of competition between different types of associations, whether they are affiliated with other Islamist movements or secular movements or are 'independent'. For all these associations, including those that serve as local conduits between the people and the public authorities (Berriane, 2009, 183), literacy classes are a privileged way of winning women's sympathies, creating propaganda for a local councillor (Berriane, 2009, 173), or encouraging women to participate in demonstrations. Again, this competition points to the very different nature of associations linked to AWI, which - while developing similar or even identical programmes - aim to instil in their offerings a different direction and occupy the 'other' dimension of development that they integrate into education programmes.

\section{Between Compliance and Discharge: Strategies of Discretion and the Price to be Paid for Existing}

For the interviewees, Assoc is an example of a 'successful' association. For not all associations manage to obtain authorisation or to carry out their activities, due to their proximity to AWI and the fact that AWI members belong to their governing bodies. The creation of associations is subject to control, and sometimes repression: an association receives its authorisation only once an investigation has been carried out into each member of its executive; and the experiences of the women members of AWI that I interviewed suggest that if that investigation reveals that one or more members of an association have any connection with the movement, the association is not authorised. Interviewees say they face many challenges on this point: 'We prepare our files properly and with respect for the law, and we deliver them to the authorities, yet they still don't grant us authorisation. They don't openly refuse; they keep telling us to come back some other time, until we finally understand that the authorities are indirectly refusing to grant us our authorisation...'22

When the authorities discover, only after granting authorisation, that a member of an association's board is connected to AWI, either they apply the 
procedure of 'arbitrary closure' of the association, or they bring a set of pressures to bear on that association's activities. Interviewees refer to 'the cancellation without notice of our activities' and 'the categorical and unexplained refusal to let us use public places for our activities. ${ }^{23}$ Faced with such repression and surveillance, AWI members deploy what I call 'strategies of discretion'. The process of creation of Assoc reveals what this discretion consists of and the precautions that are taken. For example, AWI members must convince both the neutral and its supporters that community action is important, so it is they, and not the AWI itself, who approach the authorities to file the application for authorisation. In addition, only one or two members of the movement — who should not be known to the authorities—join the executive board. The necessity of these precautions shows that the community field continues to be largely controlled by government bodies that are trying to limit the development of the network of community activities set up by their opponents. Yasmine Berriane notes that control relies on a set of processes: a preliminary inquiry is held into potential executive board members prior to the authorisation being issued; each new activity and each demonstration is the subject of a report that must be submitted to the general affairs division of the prefecture; and the presence of a representative of the local authorities is mandatory at all general assemblies (Berriane, 2009, 165). And in the case of associations linked to Islamism, Mohamed Tozy emphasises that 'the state responds to the very dense community fabric created by the Islamists by restricting public freedoms' (Tozy, 1999, 180). So these control measures also explain the above-mentioned strategies, both of adherence to dominant norms and, specifically, of compliance with hegemonic paradigms. Arguably, in the case of associations related to AWI, the at least apparent compliance of their activities and their adherence to the orthodoxy of development is a 'strategy of discretion' that makes them seem perfectly ordinary, allowing them to blend into a dense fabric of activities that do not distinguish them from other associations, do not make them particularly visible, and do not expose them to prohibition or pressure. This compliance is in large part forced, for financial reasons among others, since obtaining financial resources from the INDH and international organisations requires compliance with formal rules, but also adherence to institutional structures that embody the great ideologies of the moment. The chairs of the local committees of the INDH (often chairs of the local arrondissement) play an essential role in defining local needs and screening projects for funding (Berriane, 2009, 178). This means that any active participant who aspires to have his or her project funded must comply with the

23 Interview with an Assoc official; Casablanca, 24 January 2013. 
definitions of needs established by these local committees (Bono, 2009). Thus, the INDH works 'as an instrument for domesticating a micro-community field that is rapidly growing and difficult to control' (Berriane, 2009, 187).

But this strategy of discretion only works because public authorities are willing to let it. And they 'are willing' partly because these associations fulfil certain duties and responsibilities of the state. This is the strategy of 'turning a blind eye' or 'laissez-faire', which is a classic example of indirect government: as in other types of developmental intervention, this strategy of letting social dynamics flourish, so long as they do not fundamentally interfere with the policies or visions defended by public institutions, is commonplace and easily accepted, as it allows the state to 'discharge' 24 its responsibilities onto others so as to achieve its goals. ${ }^{25}$ In fact, women's associations have a dual function: by increasing the funding opportunities for development micro-projects at the local level, the various community players contribute to providing a sense of socio-economic security; by providing an association member with status and a more or less extensive network of connections, community action contributes to 'hiding' the problem of unemployment. What applies to associations in general also applies to those associations related to AWI. This is true of Assoc: five out of the seven members of its board have university degrees (biology, English literature, Arabic literature and Islamic studies) and two hold technical diplomas. Only three have jobs - as teachers in primary or secondary schools. The other four, including the chair of the association, are unemployed. For these women, working for the association helps mitigate the impression of having nothing to do or of being useless. ${ }^{26}$ 'Here, I can meet up with people, I can pursue different activities that give me a sense of relief even if I do them for free, and I feel useful.'27 The chair of the association says: 'When I'm seeking aid for the association or seeking to form partnerships, I go out to people; I meet important individuals (head teachers in schools, benefactors) and this gives me the opportunity to introduce myself and to demonstrate my skills, and it can also open up work opportunities.'28 So community action can be a gateway to the labour market thanks to the networks of relationships that it enables community workers to develop. Irene Bono calls community activity 'a

\footnotetext{
24 In Weber's sense, as developed by Béatrice Hibou (Hibou 1999a and 1999b).

25 This idea, inspired by the work of Michel Foucault, is highlighted by Béatrice Hibou (Hibou, 2011). See also Pereira (2009) and Meddeb (2015).

26 Many studies of community action agree that it helps to conceal the problem of unemployment (Bono, 2010; Berriane, 2009).

27 Interview with a member of the executive board of Assoc; Casablanca, 23 January 2009.

28 Interview with the chair of Assoc; Casablanca, 23 January 2009.
} 
business card' (Bono, 2010, 41). Be that as it may, this finding suggests strategies of 'discharge' since the Islamists of AWI (though the same can be said of those of the Movement of Unification and Reform (Mouvement de l'unification et de la réforme, MUR)) reject violence and support the sensitisation of young people to the virtues of non-violence through spiritual education, ${ }^{29}$ to the great benefit of both social order and the public authorities.

The charitable and benevolent activities carried out by AWI as an Islamist movement make another form of 'discharge' possible. Competition brought about by government intervention has not succeeded in excluding Islamists from the neighbourhoods, where they continue to have a presence and to influence everyday life.

Thus, the media report on the various charitable actions carried out and the assistance provided by AWI in neighbourhoods and towns where the government has clearly failed in its duty. This is the case, for example, with regard to the aid provided to those populations that, in February 2009, suffered from floods in the Gharb ${ }^{30}$ region and to the victims of a factory fire in a workingclass district in Casablanca, ignored by the authorities. ${ }^{31}$ These examples can be seen as reflecting a desire on the part of AWI to embarrass the government by forcing it to face up to its shortcomings; but we can also see them as an opportunity seized by the authorities to discharge some of its responsibilities onto AWI, even though the movement is opposed to the Moroccan regime. It is thus clear that not all outcomes are intentional, either on the government side (which in spite of itself legitimises AWI), or on the side of AWI (which unwittingly contributes to a political order that it condemns).

\section{$5 \quad$ Change the Individual to Change Society: The Different Senses Given to Education and the Conduct of Life}

In the neighbourhood under study, women members of AWI also perform activities of 'spiritual education' and 'education of consciences', acting as the

29 On spiritual education, see the following section on changing the individual. On nonviolence, see Cavatorta (2006, 214).

30 The flooding occurred in the regions of Sidi Yahya, Sidi Kacem and Sidi Slimane. News organisations even revealed that the local authorities sought help from AWI to rescue and support the people affected. See http://www.hespress.com/faits-divers/11125.html (accessed on 1 June 2016).

31 According to a community activist close to AWI, interviewed in Casablanca on 13 April 2009, AWI came to the aid of the families of fire victims who had been abandoned both by the authorities and by the officials of the factory in question. 
female section of the movement. Unlike those activities promoted by associations open to all women in the neighbourhood, these activities primarily target members of AWI.

These members follow an intense programme of spiritual activities: 'sittings', good advice and spiritual retreats. 'Sitting' is the translation of the Arabic term jalassates, commonly used by Islamists to refer to weekly religious education meetings that assemble a very limited number of members (not exceeding ten). The programme includes dhikr (litany); learning the Koran; and lessons that exhort participants to practise dhikr, citing its importance and benefits; as well as learning the basic practices of religion (ablutions, prayer). As for majlis annassiha (good advice), these are meetings that are held monthly and whose programmes are essentially based on dhikr and learning the 'moral behaviour' recommended by Islam, including 'good behaviour' such as kindness towards parents, neighbours, friends and people in general. Spiritual retreats are part of a journey towards God and are based primarily on dhikr, optional prayers, evening prayers, and so on. These programmes are part of a spiritual dimension of education that recalls the movement's adherence to Sufism. ${ }^{32}$ Focused on concern for the evolution of mankind and on mankind's ultimate destiny, spiritual education consists of programmes that constantly remind the individual that there is a hereafter and that his or her earthly life is a continuous preparation for this. Thus, through this intense spiritual programme, members are supposed to change from within and acquire strength and inner peace that will affect their daily behaviour and contribute to positive change around them, in accordance with the AWI motto: 'Change the individual to change society.'

Education is thus endowed with a specific meaning that derives directly from the connection it is supposed to have with the spiritual values present and put into practice in everyday life with the aim of changing behaviour and, thereby, of changing the ways we understand the social aspects of people's lives. In other words, following the Weberian analysis, education is understood by AWI members as a social action meant to help guide how people conduct their lives through the values it conveys, and to shape 'types of men' or, in this case, types of women. ${ }^{33}$ We can now understand the conflicts concealed behind the consensual perspective that views education as the engine

32 François Burgat believes that the personal route followed by Abdessalam Yassine illustrates both the Sufi contribution to the Islamist outlook and the urgent need to move beyond the narrow paths of the tariqua (Sufi Muslim Brotherhood) if one is to gain access to that contribution (Burgat, 1995, 20).

33 On the importance of the notions of life conduct and 'types', see Weber (2006) and Gros$\operatorname{sein}(2006)$. 
of development: the very special way in which AWI activists conduct their lives reveal interpretations of the world, and especially practices based on these interpretations, that are very different from those produced by associations of a secular persuasion, but also different from those of other Islamic associations and, of course, the government.

The spiritual education project promoted by AwI does indeed strive to be different from the religious education offered by others; its difference resides in its multidimensional aspects. To begin with, its Sufi dimension promotes another facet of development - namely, the 'change from within' realised by the above programmes (dhikr and spiritual retreats) prescribed by a spiritual guide. Yet while AwI adopts this Sufi-style approach, it differs from the latter by its ambition to supplement that approach with a struggle against injustice, which — the movement claims - can be successful only if the movement has a permanent presence among the people and provides them with support on a daily basis. It is in this sense, too, that AWI's specific character can be seen as regards development; 'conflicts' (or at least differences) with other social actors and groups on the Moroccan scene emerge: religious beliefs are made more 'everyday' and routine, and need to be placed at the service of economic and social practice and thus be more deeply embodied in the way one conducts one's life. It thus becomes easier to understand the place of 'mentoring', which involves another dimension of the educational project fostered by AWI and combines good behaviour and activism in pursuit of sociopolitical rights. Education in virtue and morality must make the AWI member into the very model of a good Muslim, who distinguishes him- or herself by good conduct; being constantly ready to help others, to defend their rights and to assist them on every level—economic, social and moral.

Meetings of the 'Sisters for Eternity': Islamist Feminism, Empowerment and Increased Conflict

At the neighbourhood level, women from AWI also organise monthly meetings open to all women. Meetings of the 'Sisters for Eternity' make concrete the project begun by women from AWI in 2000 to train women 'alimates (theologians). Although they adopt the view that Muslim women are compelled to occupy a degrading position and forced to remain marginal, AWI women believe that it is not Islam as a religion that is responsible for this situation but rather the restrictive readings of its texts, for many centuries, by an ulama, more influenced by the cultural context in which its individual members lived than by the liberating spirit of Islam. For the women of AWI, the discriminatory nature 
of classical jurisprudence vis-à-vis women is due in part to the male domination that has prevailed in the field of interpretation of sacred texts throughout the history of Islam: female scrutiny, which they consider necessary if the reading of sacred texts is to emancipate women, having been almost completely absent. It is on this basis that AWI women claim to take up the challenge of ijtihad (the effort to reinterpret and re-contextualise the sacred texts), seeking to master the necessary knowledge and to develop the tools needed to accomplish this task of reinterpretation (Yafout, 2012). This project was directly encouraged by the thought of Abdessalam Yassine and his promotion of multidimensional renewal, especially his call for the emancipation of women and their mastery of the tools of ijtihad. Thus, the alimates of AWI organise monthly meetings of the 'Sisters for Eternity' in certain cities and neighbourhoods in order to study Koranic verses, the Hadith, and historical facts that have often been interpreted by classical jurisprudence in a way that marginalises women.

So here we find another point of convergence, at least apparent, with neoliberal hegemony: the ability to empower the suppressed (and especially women) and allow them to take control; something that echoes the notion of 'empowerment' at the heart of the current dogma of international donors, but also of most development programmes in Morocco and elsewhere. Obviously, this ability is, in the case of Western developmentalist hegemony, linked to economic empowerment, while the empowerment referred to by the women of AWI results from an intellectual and spiritual effort. It is in this latter sense that certain studies describe these meetings as spaces of 'collective empowerment' (Salime, 2005, 153). But in either case, we find the same emphasis on individual action in support of women to change the way in which they are integrated into society and the world. Indeed, AWI women members reconsider the sacred texts in the light of the life of the Prophet (Sira) and the lives of his companions (men and women), but also in the light of the context in which these texts were revealed. They adopt a method that takes into account the circumstances of revelation (asbab annouzoul), the historical and social context of the text and the spirit of gradual change (attadaruj) conveyed by the koranic message. The objective of this work is to question any restrictive interpretation associating Islam with the subordination of women and to move away from any form of discriminatory theory. Thus, in the context of these meetings, controversial jurisprudential concepts are challenged, including those that refer to the superiority of men over women, or others prohibiting co-education or permitting polygamy. The 'alimates of AWI deconstruct these concepts in order to develop new ideas based on the sacred texts and historical facts. In short, the meetings of the 'Sisters for Eternity' are spaces for reflection, meant to give women back their confidence and strengthen their self-esteem by presenting 
them with the model of the emancipation of the women companions of the Prophet (sahabiyates). These companions, thanks to the place they occupied in original Islam, contributed to the construction of Muslim society through their commitment, alongside men, to supporting the Prophet and to building a new society.

Meetings of the 'Sisters for Eternity' are part of the political 'education of consciences' and 'awakening of consciences' discussed above in the context of a particular neighbourhood. The 'women' question thus involves religious, historical, and political dimensions: for the movement, the degradation of a woman's condition is linked to the monopoly of political power over the interpretation of religious texts. So we can glimpse a development conflict that opposes the movement to feminist groups and public authorities; a conflict that is hidden by the discursive consensus on the need to improve the position of women in Moroccan society.

In fact, these attempts at reinterpretation made by AWI women represent a challenge to the rule established by official Islam in Morocco, which states that the rulings of the official ulama are the benchmark for ijtihad. Many interviewees interpret the initiative of the Ministry of Habous and Islamic Affairs to train mourchidates (female preachers) as a reaction to their own plan to train 'alimates. Moreover, when it was launched, the mourchidates project was widely publicised and presented by the media-both Moroccan and international — as a revolution in the religious field and a great innovation in the Muslim world. ${ }^{34}$ Yet female preachers have played a real role, as volunteers, in Moroccan mosques since the 1970s (Yafout, 2012). The Ministry's project has merely reorganised this role in a formal setting by offering mourchidates formal training and granting them the status of paid officials. These mourchidates deal with the religious orientation of women in one or more mosques in every neighbourhood. However, mourchidates do not have the right to produce a religious interpretation or issue legal opinions, as this is the 'exclusive role of the Majlis Al IImi (scholarly council of the ulama)', according to one mourchida interviewed. ${ }^{35}$ When they explain the differences between their project and the Ministry's, AWI women members specifically mention the practice of interpretation. For them, 'alima and mourchida differ mainly on two levels: training, and the knowledge transmitted (Yafout, 2012). The 'alimates have, in their view, reached an advanced level of knowledge through specialised and extensive training, while official mourchidates have attended only short courses. Moreover, the 'alimates are able to produce scholarly knowledge, reinterpreting and

34 See, for example La Tribune (2014).

35 Interview with a mourchida for my doctoral research; 9 May 2009. 
comparing religious texts, while the role of the mourchidates is limited to giving dourous (lessons/sermons). The latter therefore are confined to passing on a less sophisticated form of religious knowledge.

Conflict with the public authorities is not always hidden. While before 2005 the meetings of the 'Sisters for Eternity' were 'tolerated', they were directly repressed from that date onwards, and opposed by the religious policy of the Ministry of Habous. The interviewees report that, before 2005, the 'Sisters for Eternity' meetings attracted many women: AWI members, sympathisers or those wishing to explore the movement's ideas or to learn religious teachings from it; their number could reach up to a thousand in certain cities or neighbourhoods. However, from May 2005 onwards, these meetings became the target of strong pressure from the authorities. They were interrupted by the police several times and the women running them were taken to the police station, questioned, and released late into the night. Faced with this situation, women members of AWI have limited the extent of their meetings and reduced the number of beneficiaries, in a strategy meant to bypass constraints by taking more precautions and adapting their activities to the new security conditions prevailing.

Between AWI and feminist movements too, the apparent consensus conceals conflicts over the values promoted by those of one or the other orientation. In fact, like secular feminists, AwI's women members aspire to women's empowerment; but, like Islamic feminists, they use the tools provided by the Islamic tradition. But they defend a 'different feminism', which advocates an analysis of the feminine condition combining historical, religious and political elements. Their reading of Muslim history links the degradation of the feminine condition in Islam to the birth of despotism and defines the enemies of women's emancipation as machismo and authoritarianism. However, AWI women members do not define themselves as feminists. On the contrary, they differentiate themselves from this movement, which they believe is part of a story quite different from that of the marginalisation of Muslim women. In their view, while religion has been a factor of discrimination against women in the West, it is—on the contrary—a factor of emancipation in the Muslim world.

Moreover, the appropriation by AwI's women members of ijtihad, conceived as a field reserved for the official ulama, partly explains the pressure exerted on them; but it also explains the conflicts within the movement. Indeed, meetings of the 'Sisters for Eternity' ceased in 2012 due to the resignation of most of the women who ran them, following differences with certain of the movement's leaders. These leaders were often hostile to the autonomy enjoyed by the women in the movement, both in the conception and the execution of 
their projects. Also, the male leaders of the movement view the interpretation of sacred texts as an exclusively male field, despite the personal position of the founder of AWI, who always, in both his theory and his practice, encouraged the female dynamic by supporting the militancy of his daughter, Nadia Yassine. The gradual withdrawal, due to illness, of the founder of the movement from 2007 onwards allowed the male leaders to begin the process of marginalising women within the movement; a process that led to these women's resignation in early 2012, a few months before the AWI founder's death. Here, development conflicts are directly related to the gender positions and stratifications that shape power relations in Moroccan society.

\section{7}

\section{Conclusion}

The example of the practice of 'development' proposed and implemented by AWI and its female institutions allows us to glimpse the great number of processes that are at work. Through this prism, the presence of AWI in the neighbourhoods is first manifested in community work, in spiritual education and the education of consciences, which results in the transmission of a vision of women's emancipation based on Islamic tradition.

The first point that emerges from this analysis is that we can only understand the ideas and actions of AWI if we take into account the complex encounter between two historically constituted matrices: firstly, the Muslim matrix, which understands development in terms of reforms (islah), but also of interpretation and contextualisation (ijtihad); and secondly, the Western matrix in the neo-liberal mode that characterises it today. Only thus can we understand that there are both formal similarities with development projects inspired by the prevailing doxa and implemented by the public authorities and other local players, and divergences in the meaning given to these same actions; a meaning which, for AWI, resides in an 'added spiritual value' combined with a quest for social justice. Which brings us to a second point: behind the consensus on the importance of development, especially education, and behind the apparent consensus on the very aims of educational action (to foster development, progress and well-being), and behind the consensus on the techniques, institutional structures, and even practices of development - a consensus partly constrained by the rules governing the funding of projects - many conflicts lie concealed; conflicts in which some strive to establish themselves in the terrain that is society in the face of competition from state actors as well as other types of actors, both Islamist and secular. There are also internal conflicts within AWI over the place of women in society. And, above all, conflicts over values, which 
reflect differences in the ways of living in society, as well as in the world and in the Hereafter, are envisaged; and related conflicts over lifestyles and how one should conduct one's life.

Education enables one to gain a deep understanding of a society, in this case Moroccan society, and to question the most widespread vision-one that sets system against anti-system. This is the third point one can make on the basis of an observation of AwI's efforts in the sphere of women's education: the complexity of relations rules out binary visions such as alignment/ repression, convergence/divergence, and competition/cooperation, although Abdessalam Yassine's movement is considered the fiercest opponent of the 'system' and sees itself as such. Thus, religious education is also fostered by other participants of society. Islamists from MUR, the PJD's religious wing, also organises religious sittings, including programmes ranging from those urging morality, to learning the Koran and the Hadith, to an introduction to Islamic jurisprudence (figh). They even carry out ad hoc ethics campaigns, employing caravans that visit cities denouncing moral depravity and calling for religious teachings to be respected. ${ }^{36}$ In mosques managed by the Ministry of Habous and Islamic Affairs, the mourchidates also teach women about their religious obligations and how to organise their daily conduct in accordance with religious principles. Since the 1980 s, religious education has been a field in which the various Islamist movements compete against the official religious authorities. The latter, especially since the 2005 reform, intervene in mosques via imams and preachers and exclude any imam propagating views opposed to their own, ${ }^{37}$ starting with the imams and mourchidates close to AWI. But this strategy of control and repression, implemented by enforcing competition in projects for development and education (both religious and non-religious education), is combined with a laissez-faire approach that allows the public authorities to discharge some of their responsibilities, voluntarily or not, and shapes existing collaborations even when the active participants themselves are unaware of this. As we can see, AwI's radical political position triggers the bans imposed by the authorities and a range of competitive strategies meant to curb the movement's influence; but at the same time, the laissez-faire attitude of the authorities allows the movement to make an undeniable contribution to solving problems at the micro-local level. Similarly, AwI continues to refuse to nominate candidates for election and will not support established policybut it is nonetheless an important political player because of the activities of

36 On the MUR's and PJD's campaigns to improve public and private morality, see Zeghal (2005, 235).

37 In this respect, Tozy mentions the dissident imams of the 1980 and contemporary imams such as Sheikh Nhari (Tozy, 2013, 148). 
proximity in which it engages. According to AWI, these activities carry a different meaning and make real the way in which Islamism is viewed as a form of daily presence among the population.

Thus the sphere in which AWI conducts its community and activist work highlights the complexity of the relationship between development and conflicts, and thus of 'development conflicts'. This is the fourth and final conclusion of this chapter. Far from conflict and pacification being seen as opposites, they are interwoven in everyday practices. The commitment of AWI members to education also explains their ability to organise demonstrations and to mobilise (Cavatorta, 2006), as was seen in the 20 February movement (BennaniChraïbi and Jeghllaly, 2012). This ability — which also brings with it a significant potential for conflict - fosters the pacification of social relations and enables some support to be given to the moral and political order. The uses of the term 'education', in its behavioural dimension, make this explicit: the word is often mentioned by AWI supporters, who say, 'they are well-educated people' (hadouk nas mrabyine). In its behavioural dimension, the term is central to the daily lives of Moroccans and is far from being typical of the movement's supporters alone. To describe the conduct of persons, use is often made of expressions such as mrabbi (well educated), ma mrabbiche (not well educated) or naques trabi (he lacks education). This ambivalent use of the term is also evident in the relations between AWI members and those around them, again highlighting the fuzziness of the meanings involved. If supporters use it in a positive way, attributing a great capacity for mobilisation to AWI members, it becomes, in other cases, a barometer to judge their conduct. 'Is that education?' (hadi hiya tarbiya?) is an expression used by individuals and groups when they encounter what they believe to be an inappropriate attitude in an AWI member; as if to judge such people by turning their own terminological corpus against them.

These four points converge to illustrate the importance of the idea of development in certain movements of contemporary Islamism. The local approach used in this chapter brings out an element too often overlooked. In fact, by focusing almost exclusively, in the case of the urban environment, on economic players and on political and community players linked to the secular world (Catusse, 2011), and, in the case of rural areas, on village development associations and migrants' associations (Lacroix, 2005), and by endeavouring to apprehend the reality (or not) of the 'social state' through its public policies, development studies in Morocco do not take Islamism into account. ${ }^{38}$ As a result, religious education and spirituality are simply not seen as playing any part

38 One exception are Tozy and Hibou (2015); however, these authors focus on the relative influence of the intellectual matrix of political Islam on daily economic practices when this 
in development, because development is linked to a form of economic rationality, including when it takes the form of 'human development'. This chapter has tried, instead, to show the richness of these dimensions and the important role they are granted both by Islamists and by the powers that be; a role that thus affords them an important role in development.

These four observations suggest another point of convergence: considering AWI as an active local participant in development, the analysis presented here has shown the complexity of the social and political relations that the Islamist movement has with power and with society as a whole. Taking into account its interaction not only with the authorities but also with the populace in general and with other local players in particular, what we see is a dialectic between conflict and consensus based on a hegemonic 'Western' model of development. This dialectic gives expression to other strategies that flourish in daily activities and other conceptions of a 'good' way of conducting one's life. Intentional or not, the strategies of discharge, differentiation, discretion, competition, or compliance, and the alternative modes of government and life conduct that this chapter has highlighted, show that relationships between the various active participants cannot be reduced to conflict or consensus, and these participants' behaviour cannot be explained solely as a form of rejection or acceptance. As Irene Bono and Béatrice Hibou show in their introduction to this volume, the neo-liberal paradigm of development can be both a common ground and a place of conflict between quite different models of society. Conflicts relating to the concept of development (economic development versus human and spiritual development) can generate consensuses that force each other to coexist in the same space, to use the same institutional structures and resort to the same models and even the same donors, and to achieve some of their goals while sacrificing others. An approach that focuses only on AWI's oppositional and political dimensions, where AWI's positions are seen as totally antithetical to those of the government and anti-hegemonic vis-àvis the West, can shed light only on the movement's oppositional dynamics. Such is the case with those elements of the literature that analyse only the vertical relationship between AWI and power, or with those that see the horizontal relationship with other political movements, particularly with secular movements, as solely and necessarily conflictual and polarising. This perspective leads analysts to study only the repression suffered by this movement or the attempts to co-opt it made by a government obsessed with its desire to maintain control over a rapidly growing and oppositional Islamism (Burgat, $2008,310-311)$. Much of the literature focuses on AwI's dissident character and

tendency is in power, and not, properly speaking, on their conceptions of 'development'. However, they do point to the importance of the 'relation to values' (Weber, 2006). 
particularly its challenge to the religious legitimacy of power: the relationship between AWI and the latter is then analysed as a struggle between counterprojects and control (Burgat, 2008; Zeghal, 2005; Tozy, 1999, 2009). Other analyses, or sometimes the same ones, also show the relationship between AWI and social movements (whether secular or inspired otherwise by Islam) as arising from conflict; whether this concerns a monopoly of political protest, strategies of appropriation of the discourse of social justice, or the control of campuses (Burgat, 2008; Zeghal, 2005; Cavatorta, 2006). AWI is not the only association to be studied in such Manichaean terms. It is clear that Islamist movements in the MENA region are most often presented as domesticated and co-opted movements (Zeghal, 2005, 193), as victims of the powers that be (Burgat, 2008), or-conversely — as a threat to the powers that be and the West (Kepel, 2000). This chapter has tried to show that beyond this threefold interpretation, while movements such as AWI-presented and presenting themselves as radicals in their position vis-à-vis power-continue to enjoy a strong following and a great capacity for mobilisation, this is partly because of the leeway that exists concretely, in everyday life, between conflict and consensus. This leeway allows each of the protagonists to achieve some of their objectives without having to yield to a domesticating consensus or a violent conflict.

\section{References}

Bennani-Chraïbi, M. and M. Jeghllaly (2012) 'La dynamique protestataire du Mouvement du 20 février à Casablanca', Revue française de science politique, 62(5), pp. 867-894, DOI: 10.3917/rfsp.625.867.

Berriane, Y. (2009) 'Intermédiations stratégiques: l'engagement de militantes associatives locales dans la campagne pour les législatives marocaines de 2007', in L. Zaki (ed.), Terrains de campagne: Les législatives de septembre 2007 au Maroc (Paris: Karthala/IRMC), pp. 161-191.

Bono, I. (2013) 'Comment devenir employable?', in B. Hibou (ed.) La bureaucratisation néolibérale (Paris: La Découverte), pp. 49-75.

Bono, I. (2010) 'Lactivisme associatif comme marché du travail: normalisation sociale et politique par les "activités génératrices de revenus" à El Hajeb', Politique africaine, 120(4), pp. 25-44, DOI: 10.3917/polaf.120.0025.

Bono, I. (2009) Cantiere del Regno. Associazioni, Sviluppo e Stili di Governo dans Morocco, doctoral thesis in political science (Turin: University of Turin).

Burgat, F. (2008) Lislamisme au Maghreb (Paris: Payot et Rivages).

Burgat, F. (1995) Lislamisme en face (Paris: La Découverte).

Catusse, M. (2011) 'Le "social": une affaire d'Etat dans le Maroc de Mohammed VI', Confluences Méditerranée, 78(3), pp. 63-76, DOI: 10.3917/come.078.0063. 
Cavatorta, F. (2006) 'Civil Society, Islamism and Democratisation. The Case of Morocco', Journal of Modern African Studies, 44(2), pp. 203-222, DOI: 10.1017/ Soo22278Xo60016o1.

Charrad, W. (2015) 'Al Adl Wal Ihsane appelle à un discours "humaniste" pour contrer le terrorisme', TelQuel, http://telquel.ma/2015/12/14/al-adl-wal-ihsane-appelle-dis cours-humaniste-contrer-terrorisme_1474173 (accessed on 1 June 2016).

Grossein, J.-P. (2006) 'Présentation', in M. Weber, Sociologie des religions (Paris: Gallimard-Tel), pp. 51-114.

Hibou, B. (2012) La bureaucratisation du monde à l'ère néolibérale (Paris: La Découverte). English translation: The Bureaucratization of the World in the Neoliberal Era, translated by Andrew Brown (New York: Palgrave Macmillan, 2015).

Hibou, B. (2011) Anatomie politique de la domination (Paris: La Découverte).

Hibou, B. (1999a) 'La décharge, nouvel interventionnisme', Politique africaine, 73(3), DOI: 10.3917/polaf.073.0006.

Hibou, B. (ed.) (1999b) La Privatisation des États (Paris: Karthala).

Kemp, A. and N. Berkovitch (2013) 'Gouvernance pédagogique et financiarisation de la vie quotidienne. La fabrique de la microfinance pour les femmes marginalisées en Israël', in B. Hibou (ed.) La bureaucratisation néolibérale (Paris: La Découverte), pp. $23-47$.

Kepel, G. (2000) Jihad, expansion et déclin de l'islamisme (Paris: Seuil).

Lacroix, T. (2005) Les réseaux marocains du développement (Paris: Presses de Sciences Po).

Meddeb, H. (2015) 'Rente frontalière et injustice sociale en Tunisie' in I. Bono, B. Hibou, H. Meddeb and M. Tozy (eds.) L'Etat d'injustice au Maghreb. Maroc et Tunisie (Paris: Karthala).

Pereira, V. (2009) 'L'émigration clandestine portugaise vers la France et les paradoxes de l'intégration européenne', Sociétés politiques comparées, 19 November, http:// fasopo.org/sites/default/files/article_n19.pdf (accessed on 31 May 2016).

Salime, Z. (2005) Between Islam and Feminism: New Political Transformations and Movements in Morocco, PhD Thesis, (Urbana and Champaign: University of Illinois).

TelQuel (2015) 'Al Adl Wal Ihsane appelle à un discours "humaniste" pour contrer le terrorisme', http://telquel.ma/2015/12/14/al-adl-wal-ihsane-appelle-discours-huma niste-contrer-terrorisme_1474173 (accessed on 1 June 2016).

Tozy, M. (2013) 'Des oulémas frondeurs à la bureaucratie du "croire"', in B. Hibou (ed.) La bureaucratisation néolibérale (Paris: La Découverte), pp. 129-154.

Tozy, M. (2009) 'Lévolution du champ religieux marocain au défi de la mondialisation', Revue internationale de politique comparée, 16 (1), pp. 63-81, DOI: 10.3917/ ripc.161.0063.

Tozy, M. (1999) Monarchie et islam politique au Maroc (Paris: Presses de Sciences Po). 
Tozy, M. and B. Hibou (2015) 'L'offre islamiste de justice sociale: politique publique ou question morale?' in I. Bono, B. Hibou, H. Meddeb and M. Tozy (eds.) L'Etat d'injustice au Maghreb. Maroc et Tunisie (Paris, Karthala).

La Tribune (2014) 'L'expérience des Mourchidates "séduit” l’Oncle Sam !' http://lnt.ma/ lexperience-mourchidates-seduit-loncle-sam/ (accessed on 1 December 2014).

Weber, M. (2006) Sociologie des religions, edited and translated by J.-P. Grossein (Paris: Gallimard-Tel).

Yafout, M. (2012) Le statut des femmes au sein des mouvements islamistes marocains: entre exégèse au féminin et participation politique, Thèse de doctorat (Casablanca: Université Hassan II).

Yassine, A. (1998) Islamiser la modernité (Casablanca: Al Ofok).

Yassine, A. (1994) Dialogue avec les honorables démocrates (Casablanca: Al Ofok).

Zeghal, M. (2005) Les islamistes marocains, Le défi à la monarchie (Casablanca: Le Fennec). 